\title{
UK is safe from Zika virus and is helping towards a vaccine, MPs hear
}

\author{
Adrian O'Dowd
}

London

The United Kingdom is "on top of" the Zika virus in terms of warning its population about avoiding certain parts of South and Central America while the national vaccine network tackles the issue, MPs have been told.

England's chief medical officer, Sally Davies, told MPs on the House of Commons science and technology committee that the issue was being treated with appropriate seriousness, during an evidence session yesterday.

On 1 February the World Health Organization declared a global public health emergency over the mosquito-borne Zika virus, ${ }^{1}$ which it fears may be causing a sharp rise in cases of babies in South and Central America being born with underdeveloped brains.

MPs on the committee, holding an evidence session to look at the chief medical officer's work, asked Davies about the connection between the virus and the rise in babies born with microcephaly and whether the link was circumstantial.

Davies said, "There is a temporal association. I understand that there are a few preliminary studies that show the virus growing in amniotic fluids and fluids surrounding the baby, and we have examples such as rubella where a virus infects early in pregnancy with the same consequences.

"So it looks as if the association is so close that, as we get more science, we are likely to find a causative link."

She added that Public Health England had given travel advice to pregnant women and those trying to get pregnant that they should think carefully before travelling to the affected areas and that anyone going there should protect themselves from mosquito bites.

The UK was prepared, said Davies, because the Department of Health and the Department for International Development had been given funding to set up a UK vaccine network. She said,
"We had already a couple of months ago started saying Zika is on our list to think, 'Do we have expertise that could develop or work in that field?'”

She said that she had met recently with one of Brazil's senior health leaders at WHO to discuss the issue and had learnt that it was set to hold a vaccine summit, which would include the UK's vaccine network chair.

"We are absolutely on top of where we need to be in Britain," said Davies. "Let me emphasise that there is no risk to people in Britain now, nor in the future. There is a risk to our people travelling, but that doesn't mean we can't help in developing vaccines and diagnostics."

MPs asked whether the budget for health research, including the National Institute for Health Research budget, had been protected as part of last year's comprehensive spending review. Davies replied, "It has, I am happy to tell you. We are in a similar position to our sister research councils."

MPs also asked about the government's progress report on its antimicrobial resistance strategy and why it still had not been published. Davies said that it had been delayed but was due to be published within the next two months.

"I understand that it concludes that we have made considerable progress in putting the building blocks in place, but we haven't yet got enough evidence that we are making a difference, so it will be the next stage in what we are doing - but there is going to be more to do," she said.

1 Gulland A. Zika virus is a global public health emergency, declares WHO. BMJ 2016;352:i657.

Cite this as: BMJ 2016;352:1692

๑ BMJ Publishing Group Ltd 2016 